\title{
Evaluation of Oxidative Stress Markers in Human Conjunctival Epithelial Cells Exposed to Diesel Exhaust Particles (DEP)
}

\author{
Romina M. Lasagni Vitar, ${ }^{1}$ Julia Tau, ${ }^{2}$ Claudia G. Reides, ${ }^{1}$ Alejandro Berra, ${ }^{2}$ Sandra M. Ferreira, ${ }^{1}$ \\ and Susana F. Llesuy ${ }^{1}$ \\ ${ }^{1}$ General and Inorganic Chemistry Division, IBIMOL UBA-CONICET, School of Pharmacy and Biochemistry, University of Buenos \\ Aires, Buenos Aires, Argentina \\ ${ }^{2}$ Ocular Investigation Laboratory, Pathology Department, School of Medicine, University of Buenos Aires, Buenos Aires, Argentina
}

Correspondence: Susana F. Llesuy, Cátedra de Química General e Inorgánica, Facultad de Farmacia y Bioquímica, Universidad de Buenos Aires, Junín 954, (C1113AAD) Buenos Aires, Argentina;

sllesuy@ffyb.uba.ar.

Submitted: March 13, 2015

Accepted: September 17, 2015

Citation: Lasagni Vitar RM, Tau J, Reides CG, Berra A, Ferreira SM, Llesuy SF. Evaluation of oxidative stress markers in human conjunctival epithelial cells exposed to diesel exhaust particles (DEP). Invest $O p h$ thalmol Vis Sci. 2015;56:7058-7066. DOI:10.1167/iovs.15-16864
Purpose. The aim of this study was to evaluate oxidative stress markers in human conjunctival epithelial cells (IOBA-NHC) exposed to diesel exhaust particles (DEP).

Methods. Reactive oxygen (ROS) and nitrogen (RNS) species production; hydrogen peroxide $\left(\mathrm{H}_{2} \mathrm{O}_{2}\right)$ levels; protein oxidation; antioxidant enzymes activities (superoxide dismutase [SOD], catalase $[\mathrm{CAT}]$, glutathione peroxidase [GPx], glutathione S-transferase [GST], and glutathione reductase [GR]); total reactive antioxidant potential (TRAP); reduced (GSH) and oxidized glutathione (GSSG) were evaluated. Transmission electron microscopy was performed to evaluate DEP uptake.

REsults. Diesel exhaust particles were entrapped by membrane protrusions developed by IOBA-NHC. Cells exposed to DEP 50 and $100 \mu \mathrm{g} / \mathrm{mL}$ showed a significant increase in ROS, RNS, $\mathrm{H}_{2} \mathrm{O}_{2}$ levels, SOD, GPx, and GST compared with the control group. A significant decay in GR was observed in both groups, meanwhile CAT levels remained unchanged. The group exposed to DEP $100 \mu \mathrm{g} / \mathrm{mL}$ displayed a significant increase in protein oxidation. In both groups, TRAP was significantly reduced as well as the GSH/GSSG ratio.

Conclusions. The decrease in nonenzymatic antioxidants and the compensatory increase of SOD, GPX, and GST activities are consequence of the increase in ROS and RNS production due to DEP exposure and its accumulation inside the cells. The decay in GR activity leads to the decrease in GSH/GSSG recycling. These results suggest that oxidative stress could play an important role in the development of DEP effects on human conjunctival epithelial cells.

Keywords: conjunctiva, oxidative stress, antioxidants, environmental pollution, diesel exhaust particles
$T^{1}$ The evidence on airborne particulate matter (PM) and its 1 public health impact is consistent in showing adverse health effects at exposures that are currently experienced by urban populations in both developed and developing countries. ${ }^{1}$ Ambient particles are known as both initiators and enhancers of the clinical manifestations of both allergic and nonallergic diseases in industrialized countries. Diesel exhaust particles (DEP) are one of main components of urban air pollution as they are the most common combustion-derived particles presented in traffic emissions. ${ }^{2,3}$

The eyes are particularly vulnerable to the effects of air pollution, as they are constantly exposed to the environment. Several studies suggest that the habitants of urban centers that are exposed to high levels of air pollutants, including DEP, often present irritation, burning, foreign body sensation, redness, and itching in the eyes. Additionally, air pollutants aggravate the symptoms and signs present in patients with dry eye or other chronic diseases of the conjunctiva. ${ }^{4-6}$ Our previous findings suggested that human conjuctival epithelial cells could elicit different adaptive mechanisms when exposed to DEP for 24 hours. We showed that DEP caused a decrease in cell viability, proliferation, and an inflammatory response mediated by interleukin (IL)-6 in human conjunctival epithelial cells. An increase in both early and late apoptotic cells and in mucin expression was also observed. ${ }^{7}$

The toxic mechanism developed in the respiratory mucosa, including epithelial and immune cells, after DEP exposure has been well-studied. ${ }^{8-10}$ It has been established that DEP chemical compounds interact with different cell targets involving oxidative stress mechanisms. Oxidative stress can be defined as an increase over physiological values in the intracellular concentrations of reactive oxygen species (ROS), that include superoxide anion $\left(\mathrm{O}_{2}^{-}\right)$, hydrogen peroxide $\left(\mathrm{H}_{2} \mathrm{O}_{2}\right)$, hydroxyl radical $\left(\mathrm{OH}^{\cdot}\right)$, peroxyl radical (ROO-) and singlet oxygen $\left({ }^{1} \mathrm{O}_{2}\right) \cdot{ }^{11}$ As reactive species damage cells and the extracellular matrix, defense mechanisms have evolved to protect them against oxidant injury. ${ }^{12-14}$ Central to these defenses are antioxidant enzymes, such as superoxide dismutase (SOD), catalase (CAT), glutathione peroxidase (GPx) and glutathione S-transferase (GST). Low molecular weight antioxidants, such as glutathione (GSH) and ascorbate, also play a central role because they are capable of free radical scavenging. The particle content of organic chemicals and transition metals presented in DEP can generate ROS and 
reactive nitrogen species (RNS). The hydroxyl radical is generated through the combination of cupper or iron metal ions with $\mathrm{H}_{2} \mathrm{O}_{2}$ by Fenton-Haber Weiss reaction. The high reactivity of $\mathrm{OH}^{\cdot}$ makes it an unselective oxidant that reacts with many biomolecules at rates approaching the diffusion limits.

The role of oxidative stress in particulate air pollution effects on ocular surface and, in particular, the involvement in the mechanism of damage after DEP exposure has not yet been reported. The aim of this study was to evaluate oxidative stress markers in human conjunctival epithelial cells (IOBA-NHC) exposed to diesel exhaust particles (DEP). In this work, we evaluate oxidative stress markers in human conjunctival epithelial cells incubated with DEP at different concentrations analyzing the changes in pro-oxidant/antioxidant balance, the antioxidant enzymes activity and the levels of nonenzymatic antioxidants. Transmission electron microscopy analysis was also performed in order to evaluate if the particles were incorporated by cells and to determine morphologic changes associated with DEP incubation.

\section{Materials ANd Methods}

\section{Cell Culture}

The normal human conjunctival epithelium cell line (IOBANHC) was provided by Yolanda Diebold, PhD (University Institute of Applied Ophthalmobiology, University of Valladolid, Valladolid, Spain). ${ }^{15}$ We grew IOBA-NHC in Dulbecco's modified Eagle's medium (DMEM)-F12 supplemented with 10\% fetal bovine serum, $2 \mathrm{ng} / \mathrm{mL}$ EGF, $5 \mu \mathrm{g} / \mathrm{mL}$ hydrocortisone, 1 $\mu \mathrm{g} / \mathrm{mL}$ bovine pancreas insulin, $50 \mathrm{U} / \mathrm{mL}$ penicillin, $50 \mu \mathrm{g} / \mathrm{mL}$ streptomycin, and $2 \mathrm{mg} / \mathrm{mL}$ amphotericin $\mathrm{B}$ in a humid atmosphere of $37^{\circ} \mathrm{C}$ with $5 \% \mathrm{CO}_{2}$.

\section{Diesel Exhaust Particles}

Diesel exhaust particles from diesel motor combustion were provided by Paulo H. Saldiva, PhD (Laboratório de Poluição Atmosférica Experimental, Faculdade de Medicina, Universidade de São Paulo, São Paulo, Brazil). Diesel exhaust particles are composed of a carbonaceous core with adsorbed organic compounds, including polycyclic aromatic hydrocarbons, and trace of inorganic compounds. ${ }^{16}$ A DEP $100-\mu \mathrm{g} / \mathrm{mL}$ suspension was made by weighing DEP, adding DMEM-F12 and sonicating in an ultrasonic bath (Ultrasonic Cleaner; Testlab, Bernal Oeste, Buenos Aires, Argentina) for 15 minutes. The suspensions of DEP 10 and $50 \mu \mathrm{g} / \mathrm{mL}$ were made from the DEP $100 \mu \mathrm{g} / \mathrm{mL}$ suspension and brought to the final volume with DMEM-F12 (serum-free medium). Finally, all DEP suspensions $(10-100 \mu \mathrm{g} /$ $\mathrm{mL})$ were sonicated for 15 minutes.

\section{IOBA-NHC Incubation With DEP}

Cell monolayers of IOBA-NHC (80\%-100\% confluent) were incubated with DEP 10,50 , and $100 \mu \mathrm{g} / \mathrm{mL}$ (DEP 10, DEP 50 and DEP 100, respectively) or with DMEM-F12 (control group) for 24 hours. Cell monolayers were washed twice with PBS 1X $(\mathrm{pH}=7.40)$. Cells were removed with $0.25 \%$ trypsin-EDTA to perform the assays. ${ }^{7}$

\section{Cell Processing for Transmission Electron Microscopy Analysis}

We incubated IOBA-NHC cells cultured in 6-well plates $(1 \times$ $10^{6}$ cells/well) with DMEM-F12 (control) or DEP at $100 \mu \mathrm{g} / \mathrm{mL}$ (DEP 100), as it was described previously. Cell samples were fixed with 3\% glutaraldehyde $0.1 \mathrm{M}$ sodium cacodylate buffer $(\mathrm{pH}=7.50)$ for 4 hours at $4^{\circ} \mathrm{C}$ and then washed with $5 \%$ sucrose in $0.1 \mathrm{M}$ sodium cacodylate buffer $(\mathrm{pH}=7.50)$. Samples were scrapped and postfixed in $1.5 \%$ osmium tetroxide in $0.1 \mathrm{M} \mathrm{K}_{2} \mathrm{HPO}_{4} / \mathrm{KH}_{2} \mathrm{PO}_{4}$ for 2 hours at $0^{\circ} \mathrm{C}$, and then dehydrated and embedded in resin (Spurr Low Viscosity Kit, Ted Pella, Inc., Redding, CA, USA) for 72 hours at $60^{\circ} \mathrm{C}$. Ultrathin sections were cut and observed with a transmission electron microscope (TEM, Zeiss EM109; Carl Zeiss Meditec, Oberkochen, Germany). Representative digital images were captured using a charge-coupled device camera (ES1000W; Gatan, Inc., Pleasanton, CA, USA). ${ }^{17}$

\section{Intracellular ROS Production}

Cells $\left(2.5 \times 10^{5}\right.$ cells $\left./ \mathrm{mL}\right)$ were loaded with $5 \mu \mathrm{M} 2^{\prime}, 7^{\prime}$ dichlorofluorescein (DCF) diacetate and analyzed by flow cytometry; DCF diacetate passively diffuses into cells, where it is de-esterified by intracellular sterases and readily oxidized to the green-fluorescent product DCF upon its reaction with oxidant species. This measurement indicates intracellular generation of oxidizing species. After a 30-minute incubation in the dark at $37^{\circ} \mathrm{C}, 50,000$ events per sample were acquired in a flow cytometer (Partec PAS-III; Partec GmbH, Münster, Germany) equipped with a 488-nm argon laser. The cell population was gated based on light scattering properties. Dichlorofluorescein signal was analyzed in the FL-1 channel with Cyflogic software (CyFlo Ltd., Turku, Finland), and quantified as median fluorescence intensities (MFI). ${ }^{18}$ The results were expressed as mean percentage increase over control cells.

\section{Intracellular $\mathrm{H}_{2} \mathrm{O}_{2}$ Concentration}

Intracellular $\mathrm{H}_{2} \mathrm{O}_{2}$ concentration was assessed by the scopoletin-horseradish peroxidase (HRP) method, measuring the fluorescence intensity at $365-450 \mathrm{~nm}\left(\lambda_{\mathrm{exc}}-\lambda_{\mathrm{em}}\right) .{ }^{19}$ Cell culture supernatants were collected and centrifuged at $10,000 \mathrm{~g}$ for 10 minutes in order to eliminate particles and cellular remains. A sample of $300 \mu \mathrm{L}$ was added to the reaction mixture containing $173 \mathrm{U} / \mathrm{mL}$ HRP and $0.1 \mu \mathrm{M}$ scopoletin in phosphate buffer $(\mathrm{pH}$ $=7.40$ ). A calibration curve with standard solution of $\mathrm{H}_{2} \mathrm{O}_{2}$ at different concentration was performed. Results were expressed as $\mathrm{nmol} \mathrm{H}_{2} \mathrm{O}_{2} / 1 \times 10^{6}$ cells.

\section{Indirect Measurement of Nitric Oxide Production}

The concentration of nitric oxide (NO) in the cell culture supernatants was determined by the accumulation of nitrite $\left(\mathrm{NO}_{2}{ }^{-}\right)$. The nitrite concentration was measured using a spectrophotometric method based on the Griess reaction. ${ }^{20}$ Cell culture supernatants were centrifuged at 10,000g for 10 minutes in order to eliminate particles and cellular remains. A sample of $400 \mu \mathrm{L}$ was mixed with $1 \%$ sulfanilamide and $0.1 \%$ naphthyl-ethylenediamine $(400 \mu \mathrm{L})$, which were allowed to react at room temperature for 10 minutes. The nitrite concentration was determined by measuring the absorbance at $550 \mathrm{~nm}$ in comparison with standard solutions of sodium nitrite at different concentration. The results were expressed as $\mathrm{nmol} / \mathrm{mg}$ protein.

\section{Protein Oxidation}

Cell content of carbonyl groups from oxidatively modified proteins were detected with $10 \mathrm{mM}$ 2,4-dinitrophenylhydrazine, which leads the formation of a stable 2,4-dinitrophenylhydrazone product that is soluble in $6 \mathrm{M}$ guanidine. The product absorbs ultraviolet light so that the total carbonyl 
content of a protein can be quantified by a spectrophotometric assay at $370 \mathrm{~nm} .{ }^{21}$ Results were expressed as nmol/mg protein.

\section{Antioxidant Enzymes Activity}

Superoxide Dismutase. A colorimetric assay was used based on the inhibition of adrenochrome formation rate at $37^{\circ} \mathrm{C}$ due to the addition of increasing amounts of cells lysate in a reaction medium consisting in $1 \mathrm{mM}$ epinephrine and $50 \mathrm{mM}$ glycine buffer $(\mathrm{pH}=10.50)$. Measurements were performed at $480 \mathrm{~nm}$ in a spectrophotometer (Hitachi U-2000; Hitachi, Ltd., Chiyoda, Tokyo, Japan). Enzymatic activity was expressed as the volume of sample needed to inhibit adrenochrome formation rate by $50 \%$ (USOD) $/ \mathrm{mg}$ protein. ${ }^{22}$

Catalase. Catalase activity was determined by measuring the decrease in absorption at $240 \mathrm{~nm}$ in a spectrophotometer (Hitachi, Ltd.). Briefly, cells lysate $(60 \mu \mathrm{L})$ was mixed in the reaction medium consisted of $100 \mathrm{mM}$ phosphate buffer $(\mathrm{pH}=$ 7.20) and $10 \mathrm{mM}$ hydrogen peroxide. The results were expressed as CAT content in $\mathrm{pmol} / \mathrm{mg}$ of protein. ${ }^{23}$

Glutathione Peroxidase. Glutathione peroxidase activity was determined by following reduced nicotinamide adenine dinucleotide phosphate (NADPH) oxidation at $340 \mathrm{~nm}$ in a spectrophotometer (Hitachi Ltd.). Briefly, cells lysate $(20 \mu \mathrm{L})$ was mixed in the reaction medium consisted of $100 \mathrm{mM}$ phosphate buffer $(\mathrm{pH}=7.50)$ in presence of $10 \mu \mathrm{M}$ reduced glutathione, $6 \mathrm{U} / \mathrm{mL}$ glutathione reductase and $10 \mathrm{mM}$ tertbutyl hydroperoxide. ${ }^{24}$ Results were expressed as $\mu \mathrm{mol} /$ min.mg protein.

Glutathione Reductase. Glutathione reductase activity was determined by following NADPH oxidation at $340 \mathrm{~nm}$ in a spectrophotometer (Hitachi, Ltd.). Briefly, cells lysate $(50 \mu \mathrm{L})$ was mixed in the reaction medium consisted of $100 \mathrm{mM}$ Tris $10 \mathrm{mM}$ EDTA buffer ( $\mathrm{pH}=8.00), 25 \mathrm{mM}$ oxidized glutathione (GSSG) and $10 \mathrm{mM} \mathrm{NADPH}$. Results were expressed as $\mu \mathrm{mol} /$ min.mg protein. ${ }^{25}$

Glutathione S-Transferase. Glutathione S-transferase activity was measured using 1 chloro- 2,4 dinitrobenzene (CDNB), which forms GS-dinitrobenzene (GS-DNB) in the presence of glutathione, reaction catalyzed by GST provided by the cell lysate. This adduct absorbs at $340 \mathrm{~nm}$. Briefly, cells lysate (50 $\mu \mathrm{L})$ was mixed in the reaction medium consisted of phosphate buffer $(\mathrm{pH}=6.50), 10 \mathrm{mM}$ glutathione $(\mathrm{GSH})$ and $20 \mathrm{mM}$ CDNB. Results were expressed as $\mathrm{mUGST} / \mathrm{mg}$ protein. One GST unit was defined as the amount of enzyme that catalyzes the formation of $1 \mu \mathrm{mol}$ GS-DNB per minute at $30^{\circ} \mathrm{C} .{ }^{26}$

\section{Total Reactive Antioxidant Potential}

Total reactive antioxidant potential (TRAP) was measured by chemiluminescence in a liquid scintillation counter (Luminoskan V 1.2-0; Thermo Labsystems Research Systems Division, Helsinki, Finland). The reaction medium consisted of $20 \mathrm{mM} \mathrm{2,}$ 2-Azobis (2-amidinopropane) and $40 \mu \mathrm{M}$ luminol. The system was calibrated with different concentrations $(0.25-0.50 \mu \mathrm{M})$ of Trolox (vitamin E hydrosoluble analogue). A comparison of the induction time after the addition of Trolox and the cells lysate $(10 \mu \mathrm{L})$ allows the calculation of TRAP as the equivalent of Trolox concentration necessary to produce the same induction time. ${ }^{27}$ Results were expressed as nmol Trolox/mg protein.

\section{GSH and GSSG Glutathione Levels}

Cells lysate samples $(100 \mu \mathrm{L})$ were mixed with $1 \mathrm{M} \mathrm{HClO}_{4}-2$ mM EDTA (1:1) and centrifuged at 20,000 $\mathrm{g}$ for 20 minutes at $4^{\circ} \mathrm{C}$. Supernatants were filtered through $0.22-\mu \mathrm{m}$ cellulose acetate membranes (Corning, Inc., Big Flats, NY, USA) and frozen at $-80^{\circ} \mathrm{C}$ until use. Analysis of HPLC was performed with liquid chromatography (Perkin Elmer LC 250; Perkin Elmer, Waltham, MA, USA), equipped with an advanced sample processor (Perkin Elmer LC ISS 200; Perkin Elmer) and an electrochemical detector (Coulochem II; ESA, Bedford, MA, USA). A silica-based HPLC column (SUPELCOSIL LC-18, $250 \times$ $4.6 \mathrm{~mm}$ ID, 5- $\mu \mathrm{m}$ particle size; Sigma-Aldrich Corp., St. Louis, MO, USA) protected by a precolumn (Supelguard, $20 \times 4.6 \mathrm{~mm}$ ID; Supelco, Bellfonte, PA, USA) was used for sample separation. We eluted GSH and GSSG at a flow rate of 1.2 $\mathrm{mL} / \mathrm{min}$ with $20 \mathrm{mM}$ sodium phosphate $(\mathrm{pH}=2.70)$, and electrochemically detected at an applied oxidation potential of $+0.800 \mathrm{~V}$. A calibration curve with both GSH and GSSG standards was performed. Results were expressed as nmol/ $1 \times$ $10^{6}$ cells. $^{28}$

\section{Chemicals}

Trolox was purchased from Aldrich Chemicals (Milwaukee, WI, USA). 2,2-Azo-bis(2-amidinopropane) was obtained from Acros Organics (Morris Plains, NJ, USA). Fetal bovine serum was obtained from Internegocios (Mercedes, Buenos Aires, Argentina). $2^{\prime}, 7^{\prime}$-dichlorofluorescein diacetate was provided by Molecular Probes (Eugene, OR, USA). All other chemicals were purchased from Sigma-Aldrich Corp.

\section{Statistical Analysis}

Statistical calculations were performed (InStat statistical package for Windows; GraphPad, San Diego, CA, USA). Data were expressed as mean \pm SEM and represent the mean of at least five independent experiments. The statistical significance of the differences between the groups was calculated by a oneway ANOVA test and Dunnett's test as a post hoc test.

\section{Results}

In order to evaluate if the particles were incorporated by cells and to determine morphologic changes associated with DEP incubation, the cell ultrastructure was analyzed by TEM. The ultrastructure of the control group was shown in Figures 1A and $1 \mathrm{~B}$. This group displayed typical cell morphology of epithelial cells. Cells had a polygonal morphology, bundles of filaments, desmosomes and microvilli. The transmission electron microscopy images of cells exposed to DEP at 100 $\mu \mathrm{g} / \mathrm{mL}$ were shown in Figures 1C through 1F. Diesel exhaust particles were clearly seen as electronic dense inclusions inside cytoplasmatic vesicles after 24 hours of incubation (Figs. 1C, $1 \mathrm{D}$, black arrows). Figures $1 \mathrm{E}$ and $1 \mathrm{~F}$ showed that there were cell membrane protrusions interacting with particles and it seemed like these membrane extensions help to entrap the particles and then form the vesicles that were accumulated inside the cell.

Cell incubation with DEP was performed for 24 hours and the ROS and RNS production as well as the enzymatic and nonenzymatic antioxidants were analyzed. ROS production was determined by flow cytometry. Cells were selected based on light-scattering properties (side scatter [SSC] versus forward scatter [FSC], Fig. 2A) and 50,000 events per sample were acquired. As shown in Figure 2B, overlaid histograms of DEP groups displayed an increase in FL-1 DCF compared to the control group. Fluorescence quantification of DCF was performed as MFI and showed that the DEP 50 and DEP 100 groups presented a significant increase in DCF oxidation (24\%, $P<0.01$ and $45 \%, P<0.001$, respectively), indicating the increase of intracellular ROS production in both groups (Fig. 3). 

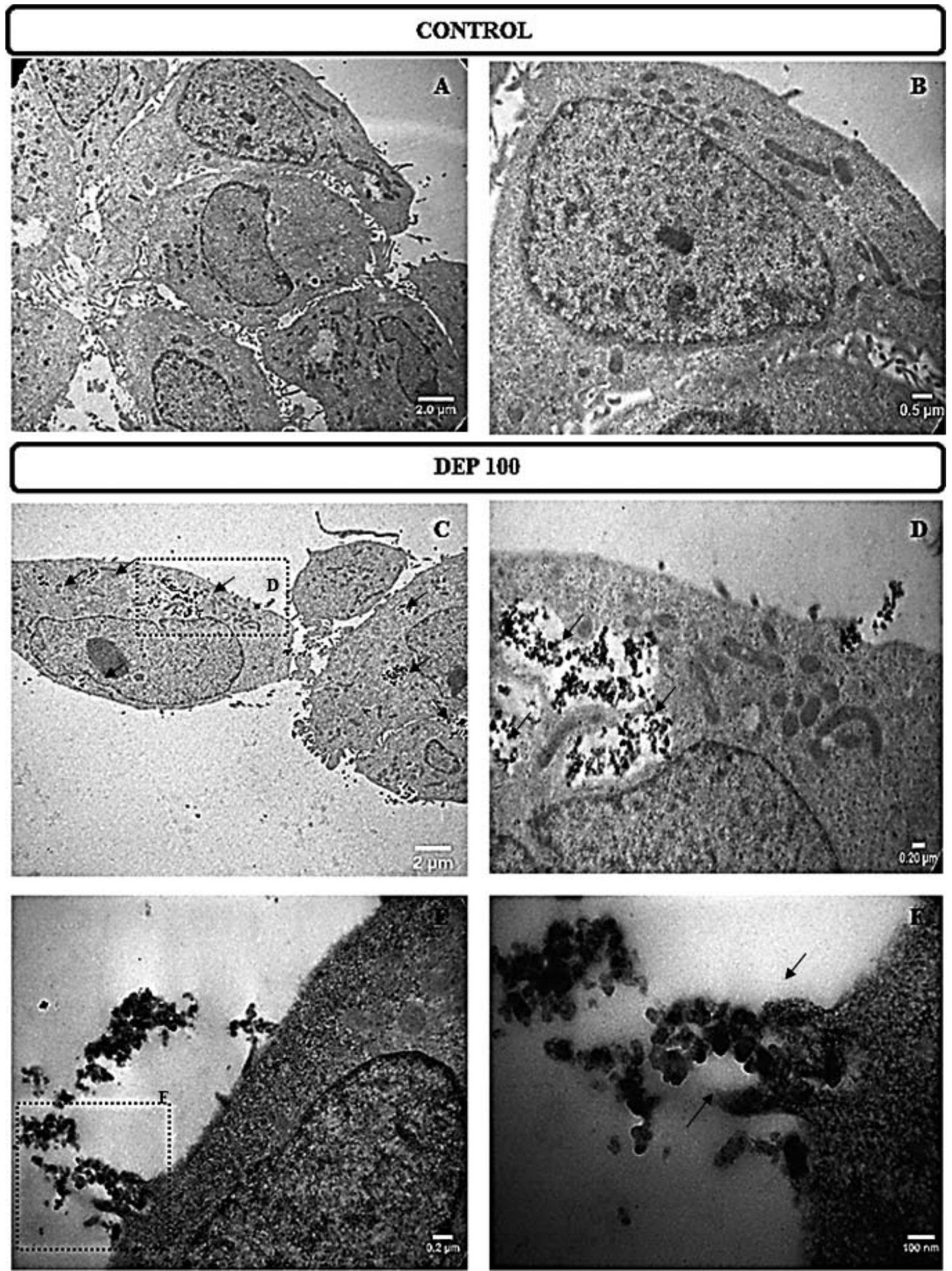

Figure 1. Representative TEM images of human conjuctival epithelial cells from control (A, B) and DEP 100 (C-F). (A, B) Control cells displayed normal cell morphology of epithelial cells. (C, D) Cells exposed to DEP at $100 \mu \mathrm{g} / \mathrm{mL}$ presented vacuoles containing particulate matter in the cytoplasm (black arrows) and also, an interaction between membrane protrusions and particulate matter was observed ([E, F], black arrows). 


\section{A}

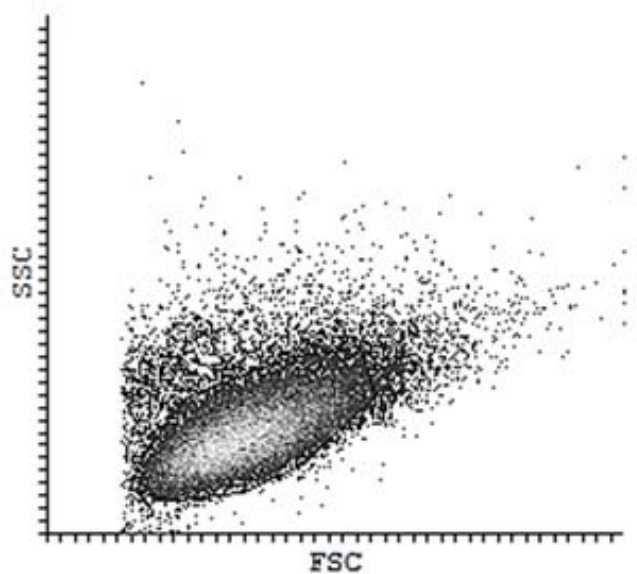

B

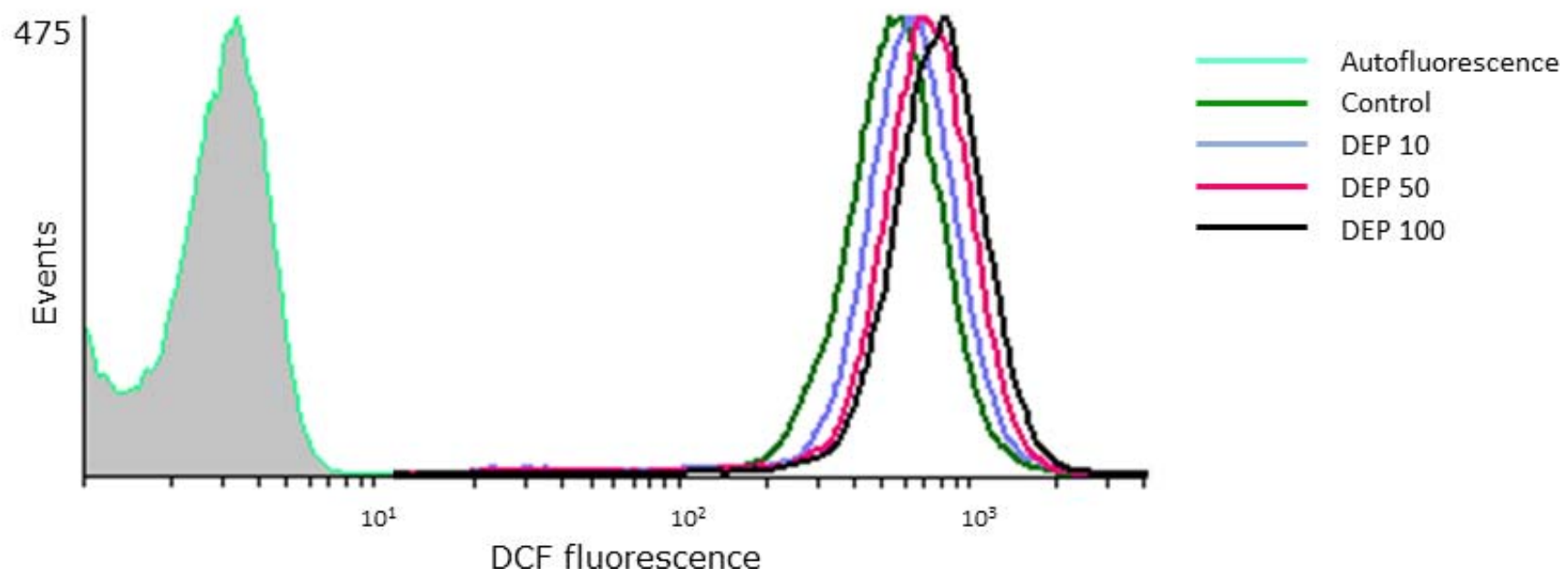

FIGURE 2. Production of ROS. (A) Cells were selected based on light-scattering properties (SSC versus FSC) and 50,000 events per sample were acquired. (B) Overlaid histograms of DEP groups displayed an increase in FL-1 DCF compared with the control group.

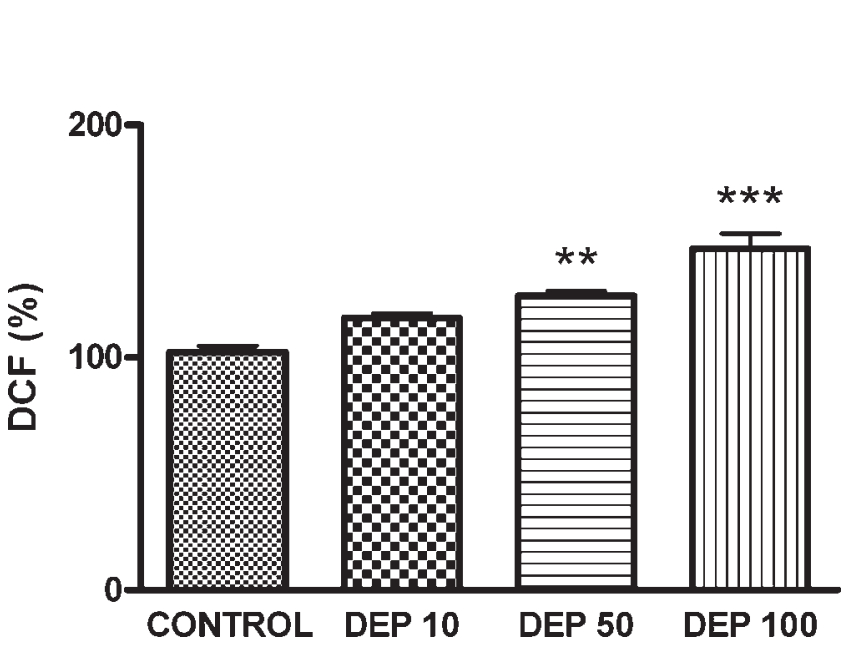

FigurE 3. Dichlorofluorescein fluorescence quantification of gated cells was performed as MFI and showed that DEP 50 and DEP 100 groups presented a significant increase in DCF oxidation. Results are expressed as percentage of increase. Results are expressed as mean \pm SEM. ${ }^{* *} P<0.01$. ${ }^{* * * *} P<0.001$.
As hydrogen peroxide can freely diffuse through cell membranes, its intracellular concentration could be approached by measuring the $\mathrm{H}_{2} \mathrm{O}_{2}$ concentration in the cell incubation medium after reaching diffusional equilibrium (intracellular concentration equals to extracellular concentration). ${ }^{29}$ In this experimental model, DEP 50 and DEP 100 groups exhibited an increase in $\mathrm{H}_{2} \mathrm{O}_{2}$ levels of $27 \%(P<0.01)$ and $73 \%(P<0.001)$, respectively, compared with the control group (Fig. 4). No significant difference was observed between DEP 10 and control groups.

An increase in NO production could be evidenced by the increase of nitrite levels, its final metabolite. ${ }^{30}$ Nitrite concentration of all groups is shown in Figure 5; DEP 50 and DEP 100 groups displayed an increase of $167 \%(P<0.05)$ and $433 \%(P<0.01)$, respectively, in comparison to the control group, indicating an increased NO production. There was no significant difference between the DEP 10 and control groups.

Protein carbonylation is used as an oxidative stress marker of protein damage. The results are shown in Figure 6. The content of oxidized proteins was found to be significantly increased by $58 \%(P<0.05)$ in the DEP 100 group, but there 


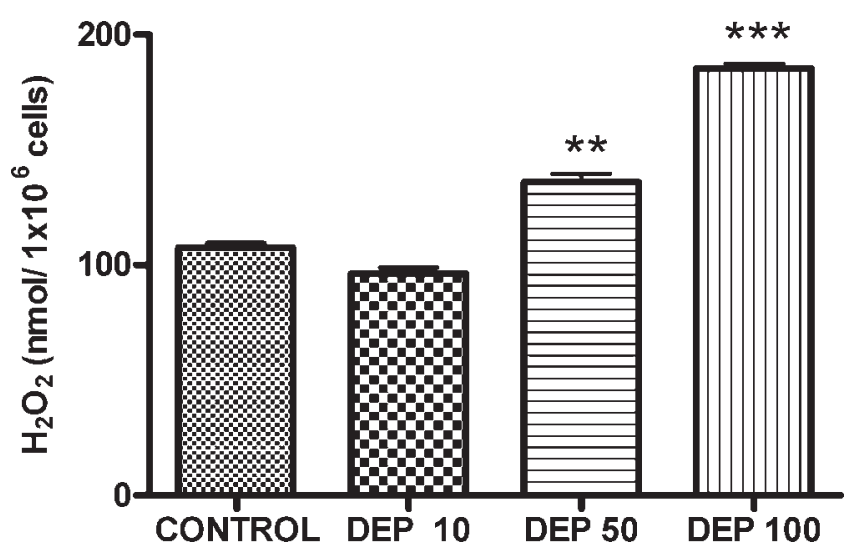

Figure 4. Intracellular hydrogen peroxide concentration; the DEP 50 and DEP 100 groups exhibited a significant increase in $\mathrm{H}_{2} \mathrm{O}_{2}$ levels compared with the control group. There was no significant difference between the DEP 10 and control groups. Results are expressed as mean \pm SEM. ${ }^{* *} P<0.01 .{ }^{* * * *} P<0.001$.

was no significant difference between DEP 10, DEP 50 and control groups.

The activities of antioxidant enzymes are presented in Table 1. Superoxide dismutase activity, a key enzyme for the detoxification of superoxide anion, was found elevated in the DEP 50 and DEP 100 groups by $84 \%$ and 104\% $(P<0.001)$, respectively. Hydrogen peroxide is metabolized by two antioxidant enzymes, CAT and GPx. We found the DEP 50 and DEP 100 groups exhibited an increase in GPx activity ( $41 \%$ and $50 \%, P<0.05$ and $P<0.01$, respectively), meanwhile CAT levels remained unchanged among all groups. Glutathione Stransferase is essential for the detoxification of toxic compounds and in this model, we found an increment in this enzyme activity ( $42 \%$ and $45 \%, P<0.01$, respectively). In order to evaluate the GSH/GSSG recycling we measured GR activity, and a significant decay in its activity was observed in DEP 50 and DEP 100 groups $(17 \%$ and $37 \%, P<0.05$ and $P<0.01$, respectively). There was no significant difference between DEP 10 and control groups in all the measurements.

Hydrosoluble nonenzymatic antioxidants levels were measured as TRAP. The results are displayed in Figure 7. Values of

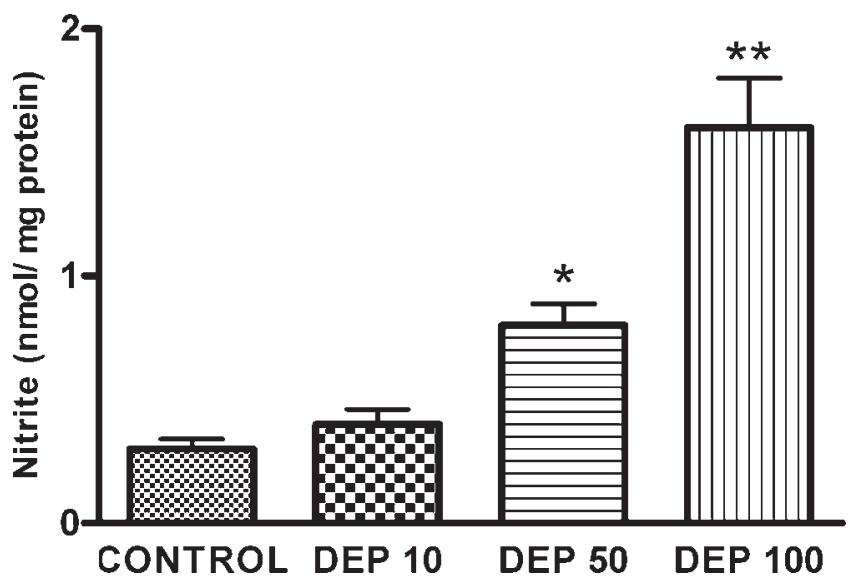

FIGURE 5. Nitrite concentration in cell culture supernatants; the DEP 50 and DEP 100 groups displayed an increase in nitrite levels in comparison to the control group, indicating an increased NO production. There was no significant difference between DEP 10 and control groups. Results are expressed as mean \pm SEM. ${ }^{*} P<0.05$. ${ }^{* *} P<$ 0.01 .

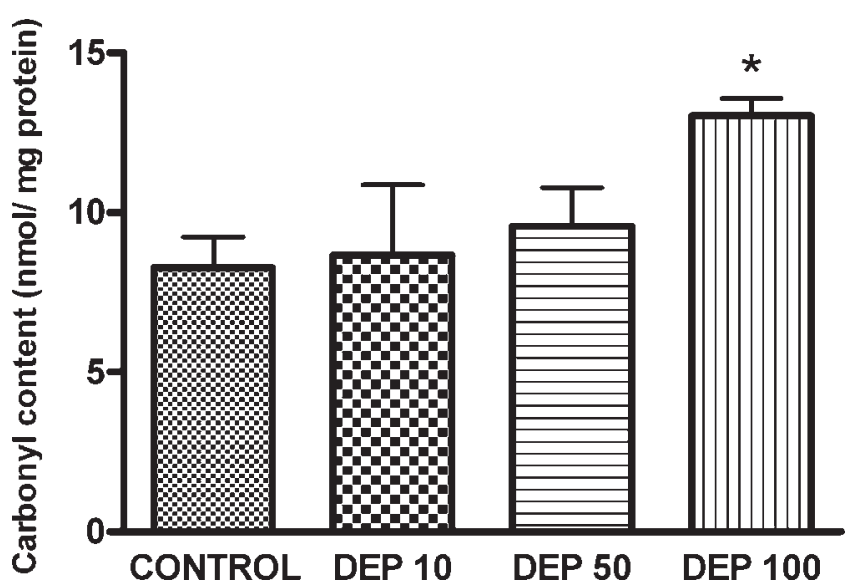

Figure 6. Protein carbonyls content. The content of oxidized proteins was found to be significantly increased in the DEP 100 group, but there was no significant difference between the DEP 10, DEP 50 and control groups. Results are expressed as mean \pm SEM. ${ }^{*} P<0.05$.

TRAP were found decreased in the DEP 50 and DEP 100 groups by $42 \%(P<0.05)$ and $58 \%(P<0.01)$, respectively, in comparison to the control group. There was no significant difference between DEP 10 and control groups.

Reduced glutathione is the most abundant low molecular weight antioxidant in mammalian cells and is oxidized to GSSG in order to detoxify a large range of oxidant species. In these experimental conditions, GSH levels were found diminished in the DEP 50 and DEP 100 groups by $42 \%(P<0.01)$ and $52 \%(P$ $<0.01$ ), respectively, comparing to the control group, but GSSG concentration showed no significant difference among all groups. As a consequence of this situation, GSH/GSSG ratio decreased in cells incubated with DEP and this parameter is commonly used to express the cell redox status (Table 2).

\section{Discussion}

Environmental pollution is a complex mixture of compounds in gaseous and solid phases. Diesel exhaust particles produced by diesel engines are a major component of particulate atmospheric pollution, and this is important, especially in urban areas where traffic emissions are the main source of air pollutants.

In the recent years, many epidemiologic studies correlate air pollution with human health effects. ${ }^{31}$ Particulate air pollution has been associated with pulmonary and cardiovascular alterations ${ }^{2,32,33}$ as well as eye discomfort. ${ }^{34}$ Although the DEP mechanism of damage in the cardiorespiratory system has been well documented, ${ }^{8,9,35}$ there are only a few experimental studies focus in eye effects.

Our work was centered in evaluating the involvement of oxidative stress in the mechanism of damage of DEP in the ocular surface, in particular, human conjunctival epithelial cells. Since a phagocytosis-like uptake of virus has been demonstrated in human conjunctival epithelial cells, ${ }^{36}$ we decided to evaluate whether these cells were capable of DEP uptake as well. It was observed that indeed DEP could be entrapped by human conjuctival epithelial cells and the interaction between plasma membrane protrusions and DEP seemed to be important for the particle uptake. The accumulation of DEP inside the cell and the interaction of DEP chemicals, including polycyclic aromatic compounds, with intracellular targets could be one of the main causes of the cytotoxic effects observed due to these particles. 
TABLE 1. Antioxidant Enzymes Activity

\begin{tabular}{lcccr}
\hline Group & $\begin{array}{c}\text { SOD, } \\
\text { U/mg Protein }\end{array}$ & $\begin{array}{c}\text { CAT, } \\
\text { pmol/mg Protein }\end{array}$ & $\begin{array}{c}\text { GPx, } \\
\boldsymbol{\mu m o l} / \mathbf{m i n} / \mathbf{m g} \text { Protein }\end{array}$ & $\begin{array}{c}\text { GR, } \\
\boldsymbol{\mu m o l} / \mathbf{m i n} / \mathbf{m g} \text { Protein }\end{array}$ \\
\hline Control & $4.95 \pm 0.68$ & $0.08 \pm 0.01$ & $0.50 \pm 0.06$ & $21.91 \pm 0.97$ \\
DEP 10 & $6.33 \pm 0.19$ & $0.07 \pm 0.02$ & $0.62 \pm 0.04$ & $19.10 \pm 1.30$ \\
DEP 50 & $9.11 \pm 0.76^{*}$ & $0.06 \pm 0.02$ & $0.70 \pm 0.04 \dagger$ & $18.10 \pm 0.82 \dagger$ \\
DEP 100 & $10.32 \pm 0.68^{*}$ & $0.08 \pm 0.02$ & $0.75 \pm 0.05 \ddagger$ & 1.04 \\
\hline
\end{tabular}

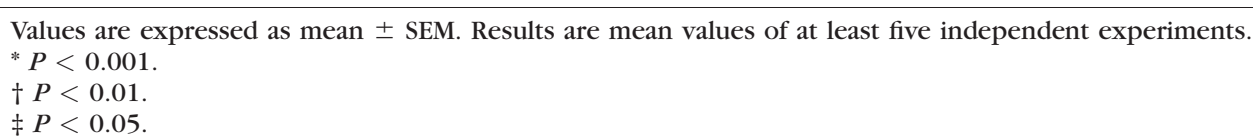

Oxidative stress can be defined as an increase over physiological values in the intracellular concentrations of ROS and RNS. ${ }^{37}$ High amounts of ROS and RNS lead to changes in the structure and function of macromolecules such as lipids, proteins, and DNA. In all cases, it is first observed as reversible damage, and then if the oxidative damage persists, irreversible cell damage takes place. In this experimental model, we found an increase in ROS and RNS production in the DEP 50 and DEP 100 groups. Furthermore, the oxidized proteins evaluated as carbonyl groups, were increased in DEP 100 group compared with the control group, indicating that there is oxidative damage in human conjunctival cells as a consequence of DEP incubation at $100 \mu \mathrm{g} / \mathrm{mL}$.

Usually, cells tolerate oxidative stress as a result of an upregulation of the antioxidant defense system in order to restore the pro-oxidants/antioxidants balance. We observed an increase in antioxidant enzymes activities in conjunctival epithelial cells exposed to DEP. We found an increase of SOD activity in the DEP 50 and DEP 100 groups. It has been reported that this antioxidant enzyme is positively modulated in inflammatory conditions as an adaptive response to oxidative stress triggered by particulate matter. ${ }^{18}$ Superoxide dismutase catalyzes the superoxide anion dismutation to $\mathrm{H}_{2} \mathrm{O}_{2}$. This molecule is an essential component in the signal transduction pathways when the concentration is greater than physiological values. ${ }^{38}$ High levels of $\mathrm{H}_{2} \mathrm{O}_{2}$ in the DEP 50 and DEP 100 groups are expected as a consequence of incremented SOD activity. Hydrogen peroxide is metabolized by two antioxidant enzymes, CAT and GPx. In this work, no significant difference in CAT levels was found among all groups. Cell survival depends on the detoxification of $\mathrm{H}_{2} \mathrm{O}_{2}$

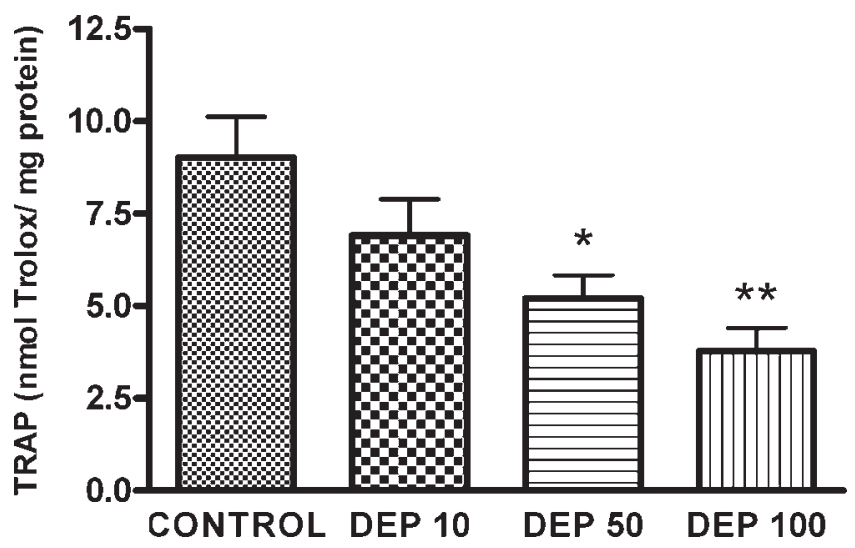

FIGURE 7. Total reactive antioxidant potential. Values of TRAP were found decreased in the DEP 50 and DEP 100 groups in comparison with the control group. There was no significant difference between DEP 10 and control groups. Results are expressed as mean \pm SEM. ${ }^{*} P<0.05$. ${ }^{* *} P<0.01$. and in this work, the DEP 50 and DEP 100 groups exhibited a significant increase in $\mathrm{H}_{2} \mathrm{O}_{2}$ levels compared with the control group. Reaction of GPx is the primary mechanism for the removal of $\mathrm{H}_{2} \mathrm{O}_{2}$ at low concentrations ( $K_{\mathrm{m}}$ value of approximately $1 \mu \mathrm{M}$ ) and catalase have not significant function below $3 \mu \mathrm{M} \mathrm{H} \mathrm{H}_{2} \mathrm{O}_{2} \cdot{ }^{39}$ In this context, $\mathrm{H}_{2} \mathrm{O}_{2}$ has to be metabolized by GPx and we found an increase in GPx activity in the DEP 50 and DEP 100 groups, confirming this hypothesis. Additionally, we observed an increment in GST activity in the DEP 50 and DEP 100 groups. This enzyme catalyzes the conjugation of reduced glutathione with hydrophobic electrophiles and ROS, and appears to play a central role in the pathogenesis of inflammatory diseases of the human airways exposed to DEP. ${ }^{40}$

The balance between the oxidized and reduced compounds is essential for normal cell function and survival. In this model, a significant decrease in nonenzymatic antioxidants evaluated as TRAP was found in the DEP 50 and DEP 100 groups. These results indicate that there is a significant reduction of hydrosoluble antioxidants of low molecular weight in both groups, such as GSH and ascorbic acid. Reduced glutathione is the major intracellular antioxidant which is readily oxidized to GSSG in order to detoxify a wide variety of oxidant species. In this study, a decrease in GSH levels was observed in the DEP 50 and DEP 100 groups, so it could be at least partially responsible for the TRAP decay. As reduced glutathione is used as a cofactor by GPx and GST, the increase of the activities of these enzymes could enhance the GSH depletion. Moreover, a decay in GR activity could also contributes to this situation, because this enzyme is crucial in GSH/GSSG recycling. Recently, it has been shown that the activity of both GPx and GR are important predictors of the general tissue redox state. ${ }^{41}$ Reduced glutathione and GSSG are the major redox pair involved in cellular redox homeostasis. A decline in the cellular GSH/GSSG ratio is regarded as a representative marker for oxidative stress and is directly responsible for the alteration of cellular function. ${ }^{9}$ We found a decrease in GSH/GSSG ratio after the incubation with DEP, indicating that there is a more oxidized environment and suggesting the occurrence of oxidative stress. A depletion in GSH levels has been shown to be associated with a number of human diseases. ${ }^{42,43}$ Reduced glutathione is a key nonenzymatic antioxidant and its decay could be ameliorated by small proteins with sulfhydryl groups such as thioredoxin. ${ }^{37}$ Further studies would be needed to complete the elucidation of the role of GSH in the DEP mechanism of damage.

Our previous study in this model demonstrated that human conjunctival epithelial cells developed a dose-dependent decrease in cell viability, proliferation, an inflammatory response mediated by IL-6 after the incubation with DEP for 24 hours. An increase in both early and late apoptotic cells was also observed. ${ }^{7}$ Taking into account these previous results and the oxidative stress markers evaluated in this study, we suggest that an inflammatory microenvironment in conjunction with 
TABLe 2. Levels of GSH and GSSG, and GSH/GSSG Ratio

\begin{tabular}{|c|c|c|c|}
\hline Group & $\begin{array}{c}\text { GSH, } \\
\text { nmol } / 1 \times 10^{6} \text { Cells }\end{array}$ & $\begin{array}{c}\text { GSSG, } \\
\text { nmol } / 1 \times 10^{6} \text { Cells }\end{array}$ & GSH/GSSG \\
\hline Control & $4.63 \pm 0.49$ & $0.50 \pm 0.10$ & 9.3 \\
\hline DEP 10 & $3.89 \pm 0.40$ & $0.53 \pm 0.12$ & 7.3 \\
\hline DEP 50 & $2.68 \pm 0.21^{*}$ & $0.46 \pm 0.06$ & 5.8 \\
\hline DEP 100 & $2.22 \pm 0.26^{*}$ & $0.41 \pm 0.07$ & 5.4 \\
\hline
\end{tabular}

Values are expressed as mean \pm SEM. Results are mean values of at least five independent experiments.

* $P<0.01$.

an increased production of ROS and RNS, develop epithelial cytotoxicity. The antioxidant response as well as the increased mucin expression previously reported could be positively modulated in inflammatory conditions in human conjunctival epithelial cells as an adaptive response to oxidative stress triggered by DEP. ${ }^{13}$ The decrease in nonenzymatic antioxidants and the compensatory increase of SOD, GPX, and GST activities are consequence of the increased ROS and RNS production due to DEP exposure and its accumulation inside the cells. The decay in GR activity leads to compromised recycling which would entail changes in the cellular redox state maintenance. However, epithelial cell capacity to maintain redox status could be exceed at highest concentration of DEP due to cumulative oxidative/nitrosative stress, resulting in a significant increase of oxidatively modified proteins and cell death.

Exposure to DEP would affect the integrity of the conjunctival epithelium and this could lead to an increased susceptibility to ocular surface pathologies and/or infections. In the present work, the results suggest that oxidative stress could play an important role in the development of DEP effects on human conjunctival epithelial cells. Further studies should be performed for the investigation of the mithochondria involvement in DEP mechanism of toxicity as well as a time course study including early time points for the better understanding of the link between the inflammatory response and the redox balance. To our knowledge, this is the first work that addresses the involvement of oxidative stress in ocular surface effects after DEP exposure and offers a novel view of air pollution impact on human eyes.

\section{Acknowledgments}

The authors thank to Lidia Margarita López for the helpful assistance with transmission electron microscopy studies.

Supported by Grants 01/796BA from University of Buenos Aires, Argentina, and Prest.BID.PICT2012-0328 from Agencia Nacional de Promoción Científica y Tecnológica (ANPCyT), Argentina.

Disclosure: R.M. Lasagni Vitar, None; J. Tau, None; C.G. Reides, None; A. Berra, None; S.M. Ferreira, None; S.F. Llesuy, None

\section{References}

1. World Health Organization (WHO). Air quality guidelines for particulate matter, ozone, nitrogen dioxide and sulfur dioxide-global update 2005: summary of risk assessment. Geneva: WHO; 2006. Available at: http://apps.who.int/iris/ bitstream/10665/69477/1/WHO_SDE_PHE_OEH_06.02_eng. pdf. Accessed October 8, 2005.

2. Ema M, Naya M, Horimoto M, Kato H. Developmental toxicity of diesel exhaust: a review of studies in experimental animals. Reprod Toxicol. 2013;42:1-17.

3. Park EJ, Roh J, Kang MS, Kim SN, Kim Y, Choi S. Biological responses to diesel exhaust particles (DEPs) depend on the physicochemical properties of the DEPs. PLoS One. 2011;6: e26749.

4. Gupta SK, Gupta SC, Agarwal R, Sushma S, Agrawal S, Saxena R. A multicentric case-control study on the impact of air pollution on eyes in a metropolitan city of India. Indian J Occup Environ Med. 2007;11:37-40.

5. Novaes P, Saldiva PH, Matsuda M, et al. The effects of chronic exposure to traffic derived air pollution on the ocular surface. Environ Res. 2010;110:372-384.

6. Saxena R, Srivastava S, Trivedi D, Anand E, Joshi S, Gupta SK. Impact of environmental pollution on the eye. Acta Ophthalmol Scand. 2003;81:491-494.

7. Tau J, Novaes P, Matsuda M, Tasat DR, Saldiva PH, Berra A. Diesel exhaust particles selectively induce both proinflammatory cytokines and mucin production in cornea and conjunctiva human cell lines. Invest Ophthalmol Vis Sci. 2013;54: 4759-4765.

8. Bayram H, Ito K, Issa R, Ito M, Sukkar M, Chung KF. Regulation of human lung epithelial cell numbers by diesel exhaust particles. Eur Respir J. 2006;27:705-713.

9. Li N, Wang M, Oberley TD, Sempf JM, Nel AE. Comparison of the pro-oxidative and proinflammatory effects of organic diesel exhaust particle chemicals in bronchial epithelial cells and macrophages. J Immunol. 2002;169:4531-4541.

10. Li N, Alam J, Venkatesan MI, et al. Nrf2 is a key transcription factor that regulates antioxidant defense in macrophages and epithelial cells: protecting against the proinflammatory and oxidizing effects of diesel exhaust chemicals. J Immunol. 2004; 173:3467-3481.

11. Sies H. Oxidative Stress. San Diego: Academic Press; 1985:1-7.

12. Li N, Nel AE. The cellular impacts of diesel exhaust particles: beyond inflammation and death. Eur Respir J. 2006;27:667678.

13. Manzo ND, LaGier AJ, Slade R, Ledbetter AD, Richards JH, Dye JA. Nitric oxide and superoxide mediate diesel particle effects in cytokine-treated mice and murine lung epithelial cellsimplications for susceptibility to traffic-related air pollution. Part Fibre Toxicol. 2012;9:43.

14. Xiao GG, Nel AE, Loo JA. Nitrotyrosine-modified proteins and oxidative stress induced by diesel exhaust particles. Electrophoresis. 2005;26:280-292.

15. Diebold Y, Calonge M, Enriquez de Salamanca A, et al. Characterization of a spontaneously immortalized cell line (IOBA-NHC) from normal human conjunctiva. Invest $O p b$ thalmol Vis Sci. 2003;44:4263-4274.

16. Laks D, de Oliveira RC, de Andre PA, et al. Composition of diesel particles influences acute pulmonary toxicity: an experimental study in mice. Inhal Toxicol. 2008;20:10371042.

17. Yanamala N, Hatfield MK, Farcas MT, et al. Biodiesel versus diesel exposure: enhanced pulmonary inflammation, oxidative stress, and differential morphological changes in the mouse lung. Toxicol Appl Pharmacol. 2013;272:373-383.

18. Marchini T, Magnani ND, Paz ML, et al. Time course of systemic oxidative stress and inflammatory response induced by an acute exposure to residual oil fly ash. Toxicol Appl Pharmacol. 2014;274:274-282.

19. Boveris A. Determination of the production of superoxide radicals and hydrogen peroxide in mitochondria. Methods Enzymol. 1984;105:429-435.

20. Ding AH, Nathan CF, Stuehr DJ. Release of reactive nitrogen intermediates and reactive oxygen intermediates from mouse peritoneal macrophages. Comparison of activating cytokines and evidence for independent production. J Immunol. 1998; 141:2407-2412.

21. Levine RL, Garland D, Oliver CN, et al. Determination of carbonyl content in oxidatively modified proteins. Methods Enzymol. 1990;186:464-478. 
22. Misra HP, Fridovich L. The role of superoxide anion in the autoxidation of epinephrine and a simple assay for superoxide dismutase. J Biol Chem. 1972;247:3170-3175.

23. Chance B, Sies H, Boveris A. Hydroperoxide metabolism in mammalian tissues. Physiol Rev. 1979;59:527-605.

24. Flohé L, Günzler WA. Assays of glutathione peroxidase. Methods Enzymol. 1984;105:114-121.

25. Racker E. Glutathione reductase from bakers' yeast and beef liver. J Biol Chem. 1955;217:855-865.

26. Habig W, Pabst M, Jakoby W. Glutathione S-transferases. The first enzymatic step in mercapturic acid formation. $J$ Biol Chem. 1974;249:7130-7139.

27. Lissi E, Pascual C, Del Castillo MD. Luminol luminescence induced by 2, 2'-Azo-bis(2- amidinopropane) thermolysis. Free Rad Res Comm. 1992;17:299-312.

28. Rodriguez-Ariza A, Toribio F, López-Barea J. Rapid determination of glutathionestatus in fish liver using high-performance liquid chromatography and electrochemical detection. $J$ Chromatogr B Biomed Appl. 1994;656:311-318.

29. Gonzalez-Flecha B, Evelson P, Sterin-Speziale N, Boveris A. Hydrogen peroxide metabolism and oxidative stress in cortical, medullary and papillary zones of rat kidney. Biochim Biophys Acta. 1993;1157:155-161.

30. Hogg N, Kalyanaraman B. Nitric oxide and lipid peroxidation. Biochim Biophys Acta. 1999;1411:378-384.

31. Li YJ, Kawada T, Azuma A. Nrf2 is a protective factor against oxidative stresses induced by diesel exhaust particle in allergic asthma. Oxid Med Cell Longev. 2013;2013:323607.

32. Magnani ND, Marchini T, Tasat DR, Alvarez S, Evelson PA. Lung oxidative metabolism after exposure to ambient particles. Biochem Biophys Res Commun. 2011;412:667-672.

33. Marchini T, Magnani N, D'Annunzio V, et al. Impaired cardiac mitochondrial function and contractile reserve following an acute exposure to environmental particulate matter. Biochim Biophys Acta. 2013;1830:2545-2552.

34. Torricelli AA, Novaes P, Matsuda M, Ruiz Alves MR, Ribeiro Monteiro ML. Ocular surface adverse effects of ambient levels of air pollution. Arq Bras Oftalmol. 2011;74:377-381.

35. Nemmar A, Subramaniyan D, Ali BH. Protective effect of curcumin on pulmonary and cardiovascular effects induced by repeated exposure to diesel exhaust particles in mice. PLoS One. 2012;7:e39554.

36. Tiwari V, Shukla D. Nonprofessional phagocytosis can facilitate herpesvirus entry into ocular cells. Clin Dev Immunol. 2012; 2012:651691.

37. Halliwell B, Gutteridge J. Free Radicals in Biology and Medicine. 3rd ed. Oxford: Clarendon Press; 1989:1-21.

38. Trachootham D, Lu W, Ogasawara MA, Nilsa RD, Huang P. Redox regulation of cell survival. Antioxid Redox Signal. 2008; 10:1343-1374.

39. Flohé L, Brand I. Kinetics of glutathione peroxidase. Biochim Biophys Acta. 1969;191:541-549.

40. Wu W, Peden DB, McConnell R, Fruin S, Diaz-Sanchez D. Glutathione-S-transferase M1 regulation of diesel exhaust particle-induced pro-inflammatory mediator expression in normal human bronchial epithelial cells. Part Fibre Toxicol. 2012;9:31.

41. Yang MS, Chan HW, Yu LC. Glutathione peroxidase and glutathione reductase activities are partially responsible for determining the susceptibility of cells to oxidative stress. Toxicology. 2006;226:126-130.

42. Ferreira SM, Lerner SF, Brunzini R, Evelson PA, Llesuy SF. Oxidative stress markers in aqueous humor of glaucoma patients. Am J Ophthalmol. 2004;137:62-69.

43. Wu G, Fang YZ, Yang S, Lupton JR, Turner ND. Glutathione metabolism and its implications for health. $J$ Nutr. 2004;134: 489-492. 